\title{
ПОРІВНЯЛЬНО-ПРАВОВА ХАРАКТЕРИСТИКА ТЛУМАЧЕННЯ ПРАВОВИХ НОРМ СУДАМИ В ЗАРУБІЖНИХ КРАÏHAX
}

\author{
АНТОШКІНА Валерія Костянтинівна - доцент кафедри галузевих \\ юридичних дисциплін Бердянського університету менеджменту і бізнесу \\ orcid.org/0000 000321363073 \\ DOI:10.32782/LAW.2020.1.4 \\ УДК 340.132.6
}

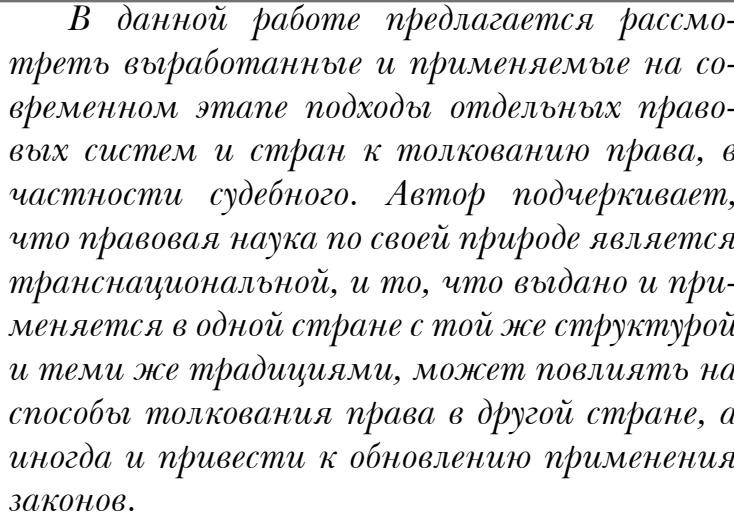

Это в значительной степени справедливо для Франиии, Германии, Англии, которвие часто определяют судебную практику многих иностранньхх государств, в которьхх их право традиционно рассматривается в качестве модели. В статье рассматриваются подходъ судей вышеупомянутых стран к толкованию правовъх норм и договоров, сравниваются их похожие и отличительные чертьл. Анализируются преимущества и недостатки каждого из таких подходов.

Также вне поля зрения автора не остались вопросъ ребормирования права во Франции, где кардинально несколько лет тому назад переписали договорное и обязательственное право, приблизив его к немеикому праву и содержанию общеевропейских актов унибикащии nрава (PECL, DCFR). Что особенно считаем необходимъим подчеркнуть, в прочессе ребормирования бълли включенъ в законодательство наработки судебной практики за многие годъ, право стало болем гибким, справедливъим и эфббективнъим.
Проанализировав заграничнъий опъгт относительно толкования права, автор подчеркивает фундаментальность этой тематики: невзирая на все отличия в подходах разньхх правовых систем, всех их объединяет одна цель: выработка надлежащей практики применения правовых норм через правильное понимание и разгяснение правовых предписаний.

Ключевъе слова: толкование нормы права, толкования норм права судом, практики толкования, способъ толкования, судебная практика, телеологическое толкование.

Видання закону або регламенту - справа влади. Проте практичне значення закону залежить від способу його застосування. Застосування ж закону припускає і певний метод тлумачення, важливість якого у наш час неодноразово підкреслювалася доктриною. У різних країнах пропонувалися найрізноманітніші методи тлумачення та правові доктрини (теорії) 3 даного питання. Тому для фундаментального вивчення вироблених підходів до тлумачення вважаємо за доцільне розглянути практики тлумачення права держав, які мають розвинену правову науку, засновану на надбаннях вчених правознавців та практиків за багато століть. Це однозначно дозволить нам збагатити свої знання в даній царині та глибше зрозуміти сутність досліджуваних явищ.

Варто відмітити, що загальні питання тлумачення правових норм та індивідуальних актів були предметом розгляду таких 
дослідників як М. Вопленко, Т. Насиров, П. Недбайло, А. Піголкін, Ю. Ткаченко, О. Черданцев, Ю. Власов, В. Карабань, А. Манукян, А. Матвєєва, Д. Михайлович, 3. Юдін, які присвятили монографічні дослідження цій проблемі. Разом 3 тим наукові надбання та практичні рекомендації більш сучасного періоду іноземних держав (20-21ст.) з вказаної теми ними мало висвітлювалися. Тільки поодинокі роботи таких вчених як М.Г. Дубінін, О. В. Чернецька, В.С. Шилінгов, Е.Н. Тонков, М.А. Матинян, Ю.В.Неділько розглядають сучасний закордонний досвід у сфері інтерпретаційної діяльності.

Саме тому в даній роботі пропонується розглянути вироблені та застосовувані на сучасному етапі підходи окремих правових систем та країн до тлумачення права, зокрема судового, щоб сформулювати своєрідні орієнтири нашій державі для формування належної практики правозастосування та регулювання правовідносин.

Досить важко визначити, який же практичний вплив кожної з цих теорій в тій або іншій країні. Законодавець 3 похвальною мудрістю ніколи не вважав, що він може встановити певні методи тлумачення; будьякі правила, які могли б бути видані ним в зв'язку з цим, не зменшили $б$ свободу тлумачення. Ніде і ніколи практика не дотримувалася тільки одного з існуючих методів тлумачення. Прагнучи знайти справедливе рішення, вона комбінує різні підходи. Кінець кінцем все залежить від психології того або іншого судді і позиції тієї школи, яку він свідомо або інтуїтивно підтримує.

Тлумачення права можна назвати вершиною юридичної майстерності і основою в питаннях правозастосування. Перш ніж застосовувати будь-який принцип або норму права в конкретній ситуації, необхідно спочатку його правильно витлумачити [3, C.131].

У всіх країнах суддя, прагнучи до того, щоб уникнути докорів у свавіллі, віддає перевагу тлумаченню, яке разом 3 буквою закону враховує і намір законодавця. Це означає, що в переважній більшості випадків суддя проводить логічне (якщо не граматичне) тлумачення, доповнене і підправ- лене в необхідних випадках зверненням до обставин прийняття відповідних нормативних актів. Але якщо того вимагає справедливість, суддя у будь-якій країні знайде спосіб відставити текст закону, що заважає йому.

Коли фактична ситуація здається досить простою, типовою, такою, що часто повторюється, то, використовуючи той або інший технічний метод, їі намагаються охопити відповідною правовою нормою, щоб зацікавлені особи знали, як їм слід поводитися. Так, французький Касаційний суд не лише контролює спосіб застосування суддями правової норми, але і дає власне тлумачення цієї норми.

Правова наука за своєю природою є транснаціональною. Так, наприклад видане і застосоване в одній країні з тією ж структурою i тими ж традиціями, що у Франції, може вплинути на способи тлумачення права в нашій країні, а іноді і привести до оновлення застосування законів без втручання законодавця. Яскравим прикладом цьому може слугувати той факт, що постанови Касаційного суду або Державної ради Франції часто визначали судову практику багатьох іноземних держав, в яких французьке право традиційно розглядалося в якості моделі.

Це ще більше явно для англомовних країн, де право створюється в основному судами: постанови вищих судів Великобританії часто зумовлюють діяльність австралійських або канадських суддів i, навпаки, за деякими австралійськими або канадськими рішеннями у Великобританії признається авторитет, майже рівний англійським прецедентам.

У деяких сучасних країнах (у Великобританії, більшості штатів СІІА, Канаді, Австралії) судовий прецедент визнається джерелом права і лежить в основі усієї правової системи. Відповідно до пануючої в них доктрини, він не створює норми, а тільки формулюе те, що витікає із загальних начал права, закладених в людській природі. у багатьох інших державах судовий прецедент використовують при вирішенні питань застосування права, заповнення прогалин в законі, визнання звичаю; на основі 


\section{Теорія, історія держави і права, конституційне право}

прецеденту вносяться окремі доповнення в чинне законодавство, дається тлумачення закону.

Підходи до вирішення багатьох правових питань в Англії є своєрідні, оскільки ця країна не сприйняла римське право, в якому основне місце займає цивільне право в якості зразка. I саме тому правова система Англії не визнає поділу права на приватне і публічне. Також не визнається виділення торгового права із норм цивільного права, як це прийнято у Франції, в Німеччині й багатьох інших країнах. Пояснюється це принципом верховенства права [11, С.350].

В Англії на сучасному етапі відносно тлумачення закону не існує суворих канонів. Отже має бути розвинене певне розуміння, як і якою мірою можна прибігати до того або іншого методу тлумачення, які шанси є для того, щоб змусити суд змінити судову практику. У Англії основна особливість полягає в тому, що ніколи не говорять про зміну судової практики, а лише про новий розвиток права шляхом застосування техніки виключень. Техніка виключень є основним технічним прийомом англійського права, яким повинен володіти англійський юрист. Фактично, використовуючи техніку виключень, в Англії приходять до потрібних результатів, не порушуючи самої будови права, подібно до того як у Франції приймають нові рішення, залишаючи зовні незміненими старі кодекси.

Раніше правило прецеденту дотримувалося надзвичайно суворо згідно вимог того часу. Зараз розвиток права вимагає більшої гнучкості в силу прискореного темпу трансформації сучасного суспільства. На континенті змогли задовольнити ці вимоги, зберігши кодекси, але встановивши гнучкіші методи тлумачення. У Англії зберігається правило прецеденту, але в тих галузях, де це необхідно, пристосовуються до вимог епохи, розробляючи нові доктрини і використовуючи техніку виключень.

Необхідно підкреслити величезну роль судового тлумачення закону. Правозастосовний орган пов'язаний не лише самим текстом закону, але і тим тлумаченням, яке дане йому в попередніх судових рішеннях - «прецеденти тлумачення».
Ще більшу свободу при тлумаченні права представляє «правило шкоди» або «правило виправлення шкоди» (англ. - mischief rule), яке застосовується для усунення двозначного розуміння норм, що містяться в положеннях права. Суть цього правила полягає в тому, що «кожний подальший закон повинен виявити помилки і недоліки попереднього, щоб усунути ці протиріччя»; у випадку якщо вони не були усунені, «саме суддя повинен інтерпретувати закон так, щоб виключити можливу шкоду нового закону, а рівно усунути прогалину в праві» $[9$, C.38].

Специфіка англійської системи права дозволяє суддям створювати прецеденти у рамках регулювання статутів, отже, їм притаманний певний елемент правотворчості, недоречний в системі континентального права. Окрім перерахованих правил, суддя лорд Альфред Томпсон Деннінг виділяв «старий граматичний підхід», який грунтується на вивченні слів в ізоляції. У разі виявлення прогалин в статуті, вони повинні опускатися до тих пір, поки не будуть усунені правотворчим органом. Інший спосіб тлумачення полягає в тому, щоб виразити основну мету, що лежить в основі права. Детальніше це правило було вироблене лордом Діплоком у справі Kammins v. Zenith Investments в 1971 році, внаслідок чого він назвав його «цільовий підхід» (англ. - purposive approach) [5, C.156-157].

Право Канади хоча і формувалося під впливом системи англійського загального права, але входить до групи американського загального права. В країні діє основний принцип цієї системи: рішення судів вищого рівня набувають силу судового прецеденту. В наші дні система канадського загального права функціонує як самостійна. Проте зберегли значення і увійшли до складу канадського загального права рішення англійських судів, прийняті раніше в результаті тлумачення чинних в Канаді англійських законів і норм загального права.

В цілому судова практика не $є$ джерелом права тому що не $є$ формою вираження норм права, а лише результатом правозастосування, тлумачення норм, в той час як 
джерело права $є$ результатом правотворчості. Дане положення грунтовно досліджено юристами англосакської правової системи, які розглядають в якості джерела права саме судовий прецедент, а не судову практику.

Важливість ролі судової практики в сучасному процесі тлумачення підтверджується постійним зростанням кількості збірок судових рішень 3 різних правових питань в таких країнах континентальної правової сім’ї, як Франція, Німеччина, Швейцарія, Італія, та в багатьох інших. Крім того вищі судові органи в цих країнах регулярно видають акти, що узагальнюють судову практику і тлумачать діючі законодавчі норми з метою їх одноманітного застосування.

Позитивістська теорія, яка вважає, що закон є винятковим джерелом права, здавалося б, безперечно перемогла в різних країнах романо-германської правової сім’ї відразу ж після кодифікації. Ця доктрина і сьогодні часто викладається студентам як загальноприйнята в цих країнах. За кордоном, особливо в країнах загального права, вважають, що вона відповідає і практиці. Насправді сталося значне пом'якшення позицій юристів. Доктрина природного права в наші дні відродилася. Самі прибічники позитивізму відмовилися від розуміння закону таким, яким він представлявся в XIX столітті; зараз вони визнають творчу роль суддів. Ніхто не вважає більше закон єдиним джерелом права і не вважає, що чисто логічне тлумачення закону може в усіх випадках привести до знаходження правового рішення [4, С.70].

Німецьке право сьогодні - це вже не «професорське право», як його називав Кошакер, протиставляючи його «праву юристів» [13]. Більше того, представляється, що право сьогодні не лише наздогнало, але i перегнало французьке право по тій ролі, яку грає в його розвитку, - в усякому разі, у ряді галузей - судова практика.

Взагалі слід підкреслити, що європейська теорія інтерпретації, на відміну від англійської, намагається окремо розглядати природу тлумачення права від тих правил, які здійснюються на практиці. Відповідно до цього виділяється теоретична і практична (юридична, судова) інтерпретація. Концепції тлумачення, розроблені юридичною наукою, також застосовуються на практиці.

Наприклад, Федеральний Верховний суд Германії вказав, що при створенні закона суб'єкт правотворчості не обмежує його дію конкретними, заздалегідь планованими випадками, тому що нормативний акт 6 не «мертвою буквою», а «живим духом», що розвивається, пристосовується до життєвих умов, і ця адаптація є корисною до тих пір, поки не виходить за рамки закону. Окрім цього, він вважає, що вирішальною для інтерпретації законодавчих положень є яскраво виражена в них воля. Для їі об'єктивного визначення необхідно звернутися до різних методів тлумачення, які доповнюватимуть один одного при дослідженні формулювання норми, їі контексту, мети, а також законодавчих матеріалів i історії прийняття. При цьому, як правило, спочатку необхідно звернутися до буквального тлумачення.

Проте слід зазначити, що в німецькій юридичній науці не визначене конкретне співвідношення різних прийомів і методів тлумачення, хоча ця обставина не означає, що тлумачення має бути довільним. Коли різні аргументи тлумачення конкурують, треба віддавати перевагу тим, які приводять до висновків, що задовольняють основному змісту закона і вимогам справедливості. Ними, головним чином, являються цілі і завдання, що стоять перед правом.

Таким чином, можна констатувати, що в Німеччині телеологічне тлумачення є вирішальним чинником в усуненні сумнівів при тлумаченні права.

Італія, де панує яскраво виражена догматична тенденція, поза сумнівом, нині ще далі від практикованих у Франції гнучких методів тлумачення. Розрив між викладанням права i судовою практикою, що існує в цій країні, ускладнює розуміння іноземцями того, як судді і практики Італії тлумачать свої закони. Навіть знайомство 3 судовими рішеннями оманливо, застерігає нас один італійський професор, оскільки ці рішення, як правило, публікуються у витримках і дуже часто саме в опущеній час- 


\section{Теорія, історія держави і права, конституційне право}

тині міститься обгрунтування прийнятого рішення.

Аналогічні зауваження можна зробити відносно іспанського і португальського права, а також права країн Аатинської Америки. Тут також сильні традиційні установки і своє головне завдання судді бачать в справедливості рішення, хоча у багатьох теоретиків цих країн в шані ті течії політичної філософії, які підкреслюють роль закону.

У Іспанії згідно ст. 1.6 ЦК «судова практика доповнюе судову систему доктриною, яку неодноразово встановлює Верховний суд в ході тлумачення і застосування закону, звичаю і загальних принципів права», незважаючи на те, що ст. 1.1 ЦК до джерел права відносить лише закон, звичай i загальні принципи права.

Таким чином, як свідчить аналіз систем права в різних країнах та правових системах судова практика не виступаючи офіційно визнаним джерелом права, все ж має велике значення, особливо в процесі тлумачення, оскільки може фактично змінювати положення закону і встановлювати зміст загальних принципів права.

Важливим при вивченні тлумачення права 6 також питання про те, наскільки інтерпретацією змінений сенс норми. В зв’язку з цим європейські дослідники тлумачення права дотримуються двох концепцій [6]:

- скептична - суть норми визначає інтерпретатор;

- формальна - завдання інтерпретатора полягає у скрупульозному встановленні істинного сенсу норми, закладеного в ній законодавцем (отже, сенс норми виник до іiі тлумачення, і розкривається лише з правильною інтерпретацією).

Цікавим в рамках тематики дослідження буде розгляд реформування в галузі цивільного права Франції. Так у 2016 році у Франції через 212 роки провели кардинальне реформування норм зобов'язального і договірного права в Кодексі Наполеона.

Французи кардинально переписали своє договірне і зобов'язальне право, наблизивши його до німецького права і змісту загальноєвропейських актів уніфікації пра- ва (PECL, DCFR) [14]. В цілому в процесі реформування були включені напрацювання судової практики за багато років, право зроблено більш гнучким, справедливим і ефективним, а отже привабливим в умовах зростаючої конкуренції європейських юрисдикцій.

В світлі проведених реформ стало актуальним питання, як відрізнити імперативні норми від норм диспозитивних в положеннях ЦК Франції про зобов’язання і договори. Розробники віддали перевагу традиційній для європейського права методології - відмова від чіткого текстуального позначення більшості норм в якості імперативних або диспозитивних.

У ряді найбільш очевидних випадків текст прямо говорить про те, що заборонено домовлятися про щось, а іноді говорить, що сторони мають право погоджувати умову, відмінну від наказаного в законі. Aле такі підказки зустрічаються в дуже невеликому числі випадків. У переважній більшості нових норм просто закріплюються ті або інші права і обов'язки сторін без чіткої ідентифікації природи норми [12].

Відповідно сталої традиції природа таких норм вважається не конкретизованою в законі, і це завдання судів шляхом теологічного тлумачення визначити їх імперативну або диспозитивну природу [1,С.332]. Загальна ідея така: за загальним правилом норми договірного права є диспозитивними (із загального принципу договірної свободи - все що прямо не заборонене, то дозволено), який у Франції має конституційне значення. Але суди можуть при тлумаченні дійти висновку і про імпліцитну імперативність відповідної норми, якщо на його погляд мета норми полягає в обмеженні договірної свободи.

Отже, можна констатувати, що розробники вирішили не відступати від укоріненої методології, заснованої на судовому телеологічному тлумаченні природи норм договірного права, вважаючи недоцільним закріпити в законі чітко, які норми імперативні, а які диспозитивні.

Слід зазначити, що дане питання піднімалося російськими вченими, зокрема Г. А. Гаджієвим, М. Г. Розенбергом, 
О. Н. Садковим, А. С. Комаровим, Д. І. Степановим, А. В. Сгоровим ат іншими. Вони виступали проти збереження в практиці судів своєї країни вже застарілого в ринкових умовах радянського підходу, згідно з яким у судів немає свободи інтерпретації і усі норми договірного права однозначно імперативні, якщо тільки в них немає прямого дозволу погоджувати інше. На практиці це призводило до того, що застосування права сторін погоджувати інше за текстом ЦК вело до виникнення багаточисленних випадково імперативних правил, блокуючих розвиток договірних відносин.

Пленум ВАС РФ прийняв Постанову «Про свободу договору і їі межі» в 2014 році, яка закріпила загальноєвропейську і зокрема характерну для французького права методологію тлумачення норм договірного права, засновану на судовому телеологічному тлумаченні норм, що не мають прямого текстуального атрибуту імперативності або диспозитивності [7].

Проте ця методологія поширюється зараз виключно на практику арбітражних судів і практику Судової колегії з економічних спорів ВС РФ, яка активно застосовує ці принципи тлумачення, закріплені в Постанові Пленуму ВАС [2].

Отже, при тлумаченні спірних норм вибір на користь імперативності повинен сприйматися як виняток із загального правила і всякий раз переконливо обгрунтовуватися в судовому рішенні, на що прямо вказується у Постанові Пленуму ВАС «Про свободу договору і її межі».

Названа постанова заслуговує на увагу з боку білоруського законодавства. У Білорусі правозастосовна практика грунтується на буквальному тлумаченні норм договірного права, за відсутності в нормі прямої вказівки на допустимість ії зміни домовленістю сторін така норма застосовується як імперативна.

У зв'язку з цим необхідно визначення норм в якості імперативних незалежно від формальних ознак повинно бути застосовно не лише у сфері приватних відносин, ускладнених іноземним елементом. Отже доцільно для забезпечення реалізації сторонами принципу свободи договору ви- користати механізм телеологічного тлумачення, спрямований на виявлення цільової спрямованості норми, навіть при іï формально імперативному закріпленні в законодавстві, що пропонується закріпити на рівні постанови Пленуму Верховного Суду Республіки Білорусь.

Характеризуючи процес тлумачення в США слід враховувати, що діє компетенція не федеральної влади, а кожного з штатів. При цьому система права у різних штатах має багато відмінностей, які переважно пов'язані із законодавчими рішеннями, але бувають і наслідком тлумачення загального права. Значні відмінності по штатах має судова система, цивільний і кримінальний процес (наприклад, підстави і умови розлучення, спільність та роздільність майна подружжя, відмінності у праві товариств i т. ін.). Проте слід відмітити, що Верховний суд США суттєво змінив конституційне розділення повноважень між федерацією i штатами шляхом тлумачення формул конституційного тексту і поправок. Зокрема штати зобов'язали поважати деякі загальні принципи, як на законодавчому рівні, так і у судовій практиці [10, C.125].

Слід підкреслити схожість підходів англійських і американських юристів тому, що право - це передусім судова практика, а норми закону входять в систему права лише після того, як неодноразово застосовані і представлені суддями. У американських судах, також як і в англійських, перевагу віддають посиланню не на закони, а на судові рішення, де вони застосовані.

Тлумачення законів в країнах соціалістичного напряму мало чим відрізняється від прийнятого в СРСР. Воно має бути суворим, що неодноразово підкреслювалося в юридичній літературі цих країн. Проте так підходять до тлумачення лише нового права. Що стосується законів, успадкованих від минулого, які залишаються в силі, то діють інші критерії.

Проте старі закони поступово сходили зі сцени, а відносно нових у результаті дискусії були вироблені гнучкіші принципи тлумачення, сприяючі посиленню зв'язку між правом і життям суспільства. Конституція ЧССР 1960 року в ст. 102 встановила, 


\section{Теорія, історія держави і права, конституційне право}

що судді повинні тлумачити закони відповідно до соціалістичної правосвідомості, і це правило було розвинене в Цивільному кодексі 1964 р.

Навряд чи можна погодитися 3 ідеєю болгарського дослідника Б. Спасова про те, що під тлумаченням закону слід розуміти виключно загальнообов'язкове роз'яснення сенсу правової норми [8, С.143]. Цілком зрозуміло, що тлумачення більше і багатоаспектне явище юридичної практики.

В Україні не існує спеціального закону, присвяченого тлумаченню права, як в деяких інших державах, наприклад, в Канаді діє Interpretation Act 1975 р., але окремі норми про тлумачення права містяться в Конституції України, Цивільному кодексі та інших законодавчих актах.

Отже, у світі одна система права може носити релігійний характер, і ніякий законодавець не може змінювати норми такого права. У інших країнах закони - лише модель, яку вважають можливим порушувати, якщо того вимагає звичаї. Де-небудь ще судовому рішенню надається значення, що виходить за рамки цього процесу. Використання загальних принципів і формул також може в деяких правових системах служити для того, щоб підправити в ту або іншу сторону формальну норму діючого права. Справа ускладнюється тим, що висновки теоретиків про джерела права або способи тлумачення закону не завжди дають точне уявлення про реальне положення. Так, доктрина у Франції стверджує, що судова практика не є джерелом права; проте насправді при певних обставинах рішення Касаційного суду або Державної ради часто грають роль не меншу, ніж закон. Ще і сьогодні в Англії закон охоче зображують як винятковий феномен в системі, яка є класичною системою суддівського права. Проте закони в Англії такі ж численні, і вони грають там роль анітрохи не меншу, ніж у Франції. Їх перестали тлумачити буквально і обмежувальне, як це пропонувалося старовинними канонами. Залишається вірним лише те, що англійські юристи як і раніше погано почувають себе у присутності норм, сформульованих за- конодавцем, і прагнуть якнайшвидше розчинити їх в судових рішеннях, винесених в ході застосування цих норм. Доктрина ісламу не допускає, щоб законодавець міг змінювати норми права, що становлять священне мусульманське право; ця заборона не перешкоджає тому, щоб різними шляхами - поліцейськими або процесуальними - володар в мусульманських країнах фактично паралізував дію тієї або іншої норми або підпорядкував їі застосування різним умовам, не торкнувшись ортодоксальних принципів.

Проаналізувавши закордонний досвід щодо тлумачення права, варто ще раз підкреслити фундаментальність цієї тематики: незважаючи на всі відмінності у підходах різних правових систем, всіх їх об'єднує одна мета: вироблення належної практики застосування правових норм через правильне розуміння та роз'яснення правових приписів.

Також в сучасному глобальному світі, який характеризується тісною взаємодією та взаємним проникненням, особливо в інтелектуальній сфері, комунікаціях, не можна не знати і не вивчати інший позитивний успішний досвід. Отже з'ясування специфіки судового тлумачення в різних країнах дозволить збагатити вітчизняну юридичну науку та виробити, осучаснити певні підходи до вказаних питань, як осіб, що застосовують право так і осіб, які творять нові закони та потребує подальшого розгляду та вивчення.

\section{Лiтература}

1. Антонов М.В. Современная теории права во Франции: реалистический подход к праву в концепции Мишеля Тропера и спор о неореализме в толковании // Российский ежегодник теории права. - 2012. - № 4. - С. 321-345.

2. Визначення КЕС ВС РФ від 27.10.2015 р. № 305-EC15-6784, від 29.03.2016 р. № 306-EC15-16624 і від 25.08.2016 p. № 301-EC16-4469.

3. Дубинин М.Г. Толкование права в романо-германской и англосаксонской правовых семьях (на примере ФРГ и Великобритании) // Вестник Нижегородского 
университета имени Н.И. Аобачевского. Серия «Право». - 2015. -№3. - С.131-137.

4. Аярская Н.С Воздействие Институциональной среды на формирование Государственной модели корпоративного управления // Әкономический вестник Ростовского муниципального института. 2006. - Том 4. - № 2. - С. 70-88.

5. Матинян М.А. Место и роль закона в системе источников права Англии // Общество: политика, экономика, право. - 2008. - № 2. - С. 150-163.

6. Недилько Ю.В. Особенности толкования права в Германии: взаимодействие теории и практики // Евразийский юридический журнал. - 2015. - № 10 (89). - Режим доступа: http://www. eurasialaw.ru/index.php?option $=\mathrm{com}$ content\&view $=$ article $\&$ id $=79142015-12-23$ 06-15-34\&catid=183:2010-12-13-11-46-22.

7. Постановление Пленума ВАС РФ «О свободе договора и ее пределах» от 14.03. 2014 г. № 16.

8. Спасов Б. П. Закон и его толкование. - М., 1986. - 247c.

9. Тонков Е.Н. Английская техника толкования закона // Вестник Нижегородской академии МВД России. - 2013. - № 24. - C. 37-40.

10. Тонков Е.Н. Толкование закона в Англии / Евгений Тонков. - М.: Издательство «Алетейя», 2013. - 356 с.

11. Чернецька О.В., Шилінгов В.С. Право Англії як класична модель прецедентного права // Правова система України й міжнародне право, порівняльне правознавство. - 2015. -№4. - С.348-352.

12. Cecile Perez "Mandatory and Non - Mandatoru Rules in the New Law of Contract". // "The Code Napoléon Rewritten : French Contract Law after the 2016 Reforms". Studies of the Oxford Institute of European and Comparative Law) 1st Edition, Kindle Edition. - 2017. - 536p..

13. Gunter Wesener: Paul Koschaker (1879-1951), Begründer der altorientalischen Rechtsgeschichte und juristischen Keilschriftforschung, in: Karl Acham (Hrsg.): Rechts-, Sozial- und Wirtschaftswissenschaften aus Graz, Wien/Köln/Weimar 2011, S. 273-285.

\section{АНОТАЦІЯ}

В даній роботі пропонується розглянути вироблені та застосовувані на сучасному етаnі підходи окремих правових систем та країн до тлумачення права, зокрема судового. Автор підкреслює, шо правова наука за своєю природою $є$ транснаціональною, $i$ видане $i$ застосоване в одній краӥні з тією ж структурою $i$ тими ж традиціями, може вплинути на способи тлумачення права в іншій країні, а іноді і привести до оновлення застосування законів. Це значною мірою справедливо для Франиї, Німеччини, Англї, які часто визначають судову практику багатьох іноземних держав, в яких їх право традииійно розглядається в якості моделі. В статті розглядаються підходи суддів вищезазначених країн до тлумачення правових норм і договорів, порівнюються їх схожі та відмінні риси. Аналізуються переваги та недоліки кожного з таких підходів.

Проаналізувавши закордонний досвід щодо тлумачення права, автор підкреслюе фбундаментальність ијеї тематики: незважаючи на всі відмінності у підходах різних правових систем, всіх їх об’єднує одна мета: вироблення належноӥ практики застосування правових норм через правильне розуміння та роз'яснення правових приписів.

Ключові слова: тлумачення норми права, тлумачення норм права судом, практики тлумачення, способи тлумачення, судова практика, телеологічне тлумачення.

14. Principles, Definitions and Model Rules of European Private Law. Draft Common Frame of Reference (DCFR). Prepared by the Study Group on European Civil Code and the Research Group on EC Private Law (Acquis Group). Based in part on a revised version of the Principles of European Contract Law. -4795 p.

\section{Antoshkina Valeriya \\ COMPARATIVE-LEGAL CHARACTERISTICS OF THE INTERPRETATION OF LEGAL RULES BY COURT IN FOREIGN COUNTRIES}

This paper proposes to study the approaches to the interpretation of law, in particular judicial, developed and applied at the 


\section{Теорія, історія держави і права, конституційне право}

present stage by individual legal systems and countries. The author emphasizes that legal science is transnational in its nature and what is published and applied in one country of the same structure and traditions, can influence on the ways of law interpretation in another country and sometimes lead to a renewing of the laws application.

It is largely true for France, Germany, England, which often influence on the court practice of many foreign states in which their law is traditionally considered as a model. The article studies the approaches of judges of the above-mentioned countries to the interpretation of legal rules and treaties, their similar and distinctive features are compared. The advantages and disadvantages of each of these approaches are analyzed.

Also outside the author's view there were no issues on reforming the law in France, where a few years ago, they fundamentally rewrote contractual law and law of obliga- tions, bringing it closer to German law and to the content of pan-European acts of unification of law (PECL, DCFR). We particularly consider necessary to emphasize that, in the course of reform, the case law has been incorporated into the legislation for many years, the law has become more flexible, fair and effective.

Having analyzed the foreign experience regarding the interpretation of law, the author emphasizes the fundamentality of this topic: despite all the differences in the approaches of different legal systems, all of them are united by one goal: developing of a good practice of application of legal norms through proper understanding and clarification of legal regulations.

Keywords: interpretation of the legal norms, interpretation of the rules of law by a court, interpretation practices, ways of interpretation, court practice, teleological interpretation. 